\title{
A Computerized Data Base of Nitrate Concentrations in Indiana Ground Water
}

\section{By MARTIN R. RISCH and DAVID A. COHEN}

Prepared in cooperation with the INDIANA DEPARTMENT OF ENVIRONMENTAL MANAGEMENT

U.S. GEOLOGICAL SURVEY Open-File Report 95-468

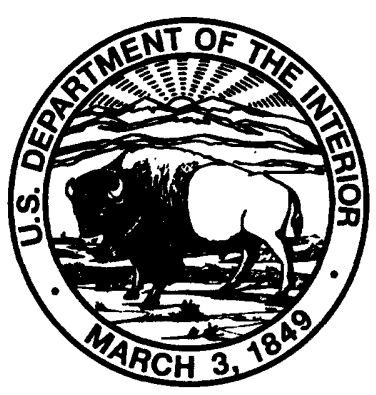

Indianapolis, Indiana 1995 


\title{
U.S. DEPARTMENT OF THE INTERIOR BRUCE BABBITT, Secretary
}

\author{
U.S. GEOLOGICAL SURVEY \\ Gordon P. Eaton, Director
}

For additional information, write to:

District Chief

U.S. Geological Survey

Water Resources Division

5957 Lakeside Boulevard

Indianapolis, IN 46278-1996
Copies of this report can be purchased from:

U.S. Geological Survey

Earth Science Information Center

Open-File Reports Section

Box 25286, MS 517

Denver Federal Center

Denver, CO 80225 


\section{CONTENTS}

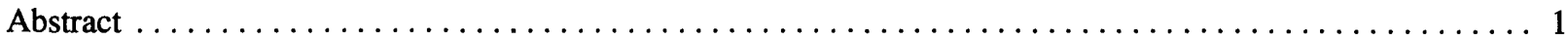

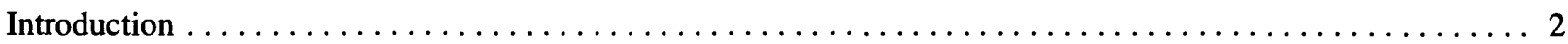

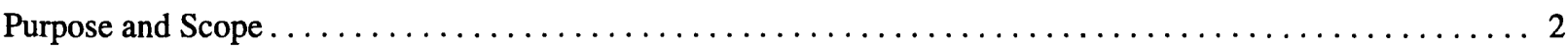

Computerized Data Base of Nitrate Concentrations in Indiana Ground Water $\ldots \ldots \ldots \ldots \ldots \ldots \ldots \ldots \ldots 2$

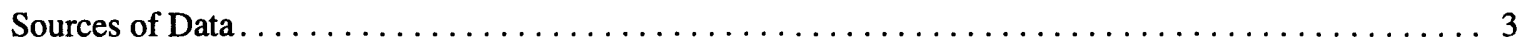

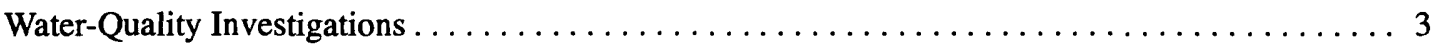

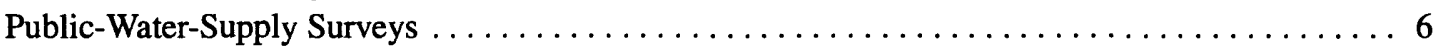

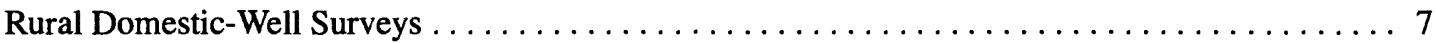

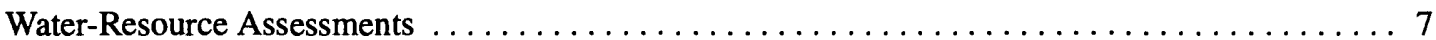

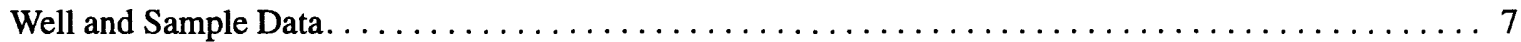

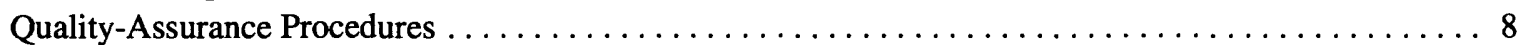

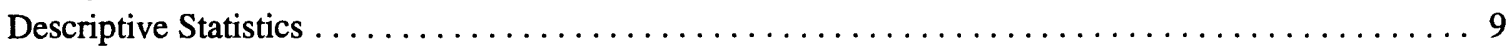

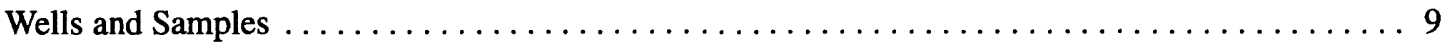

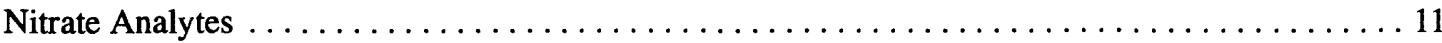

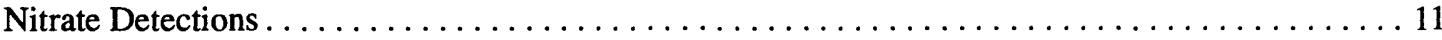

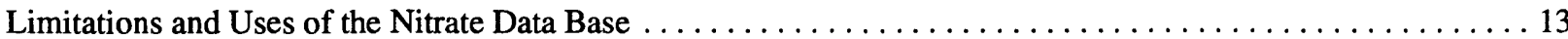

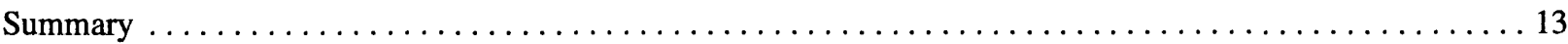

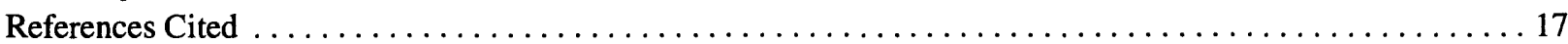

\section{FIGURES}

1. Map showing locations of drinking-water-supply wells in Indiana with nitrate concentrations greater than or equal to 10 milligrams per liter during $1973-91 \ldots \ldots \ldots \ldots \ldots \ldots \ldots \ldots \ldots \ldots \ldots \ldots \ldots \ldots \ldots$

2. Graph showing percentages of samples with nitrate concentrations greater than or equal to 3 milligrams per liter and greater than or equal to 10 milligrams per liter $\ldots \ldots \ldots \ldots \ldots \ldots \ldots \ldots$

\section{TABLES}

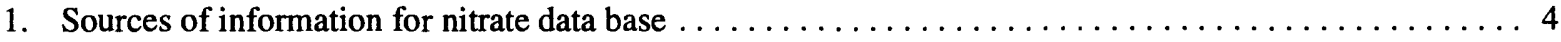

2. Sample-collection procedures and analytical methods $\ldots \ldots \ldots \ldots \ldots \ldots \ldots \ldots \ldots \ldots \ldots$

3. Counties and number of sites from the Indiana non-community-water-supply survey not

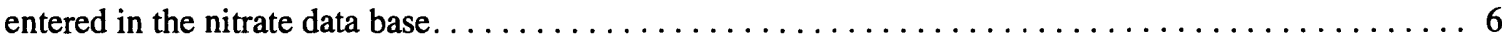

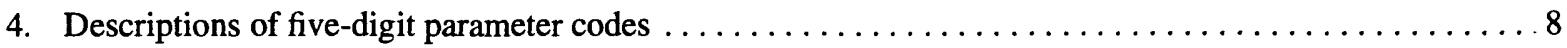

5. Descriptions of fixed-value codes for collecting and analyzing agency $\ldots \ldots \ldots \ldots \ldots \ldots \ldots \ldots, 8$

6. Number of wells and samples per county in the nitrate data base $\ldots \ldots \ldots \ldots \ldots \ldots \ldots \ldots \ldots \ldots$

7. Distribution of samples and nitrate-analyte determinations in the nitrate data base $\ldots \ldots \ldots \ldots \ldots 11$

8. Number of nitrate-analyte determinations per minimum reporting limit $\ldots \ldots \ldots \ldots \ldots \ldots \ldots \ldots 12$

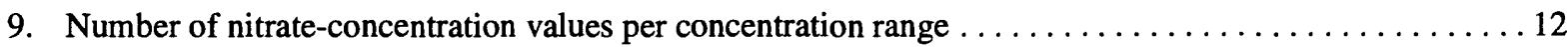


CONVERSION FACTORS AND ABBREVIATED WATER-QUALITY UNITS

\begin{tabular}{lll}
\hline Multiply & By & To obtain \\
\hline inch (in.) & 25.4 & millimeter \\
\hline
\end{tabular}

Temperature is given in degrees Celsius $\left({ }^{\circ} \mathrm{C}\right)$, which can be converted to degrees Fahrenheit $\left({ }^{\circ} \mathrm{F}\right)$ by use of the following equation:

$$
\mathrm{F}=1.8\left({ }^{\circ} \mathrm{C}\right)+32
$$

Abbreviated water-quality units used in this report: Chemical concentrations and water temperature are given in metric units. Chemical concentration is given in milligrams per liter $(\mathrm{mg} / \mathrm{L})$ or micrograms per liter $(\mu \mathrm{g} / \mathrm{L})$. Milligrams per liter is a unit expressing the concentration of chemical constituents in solution as weight (milligrams) of solute per unit volume (liter) of water. For concentrations less than $7,000 \mathrm{mg} / \mathrm{L}$, the numerical value is the same as for concentrations in parts per million.

Specific conductance of water is expressed in microsiemens per centimeter at 25 degrees Celsius $(\mu S / \mathrm{cm})$. This unit is equivalent to micromhos per centimeter at 25 degrees Celsius $(\mu \mathrm{mho} / \mathrm{cm})$, formerly used by the U.S. Geological Survey. 


\title{
A Computerized Data Base of Nitrate Concentrations in Indiana Ground Water
}

\author{
By Martin R. Risch and David A. Cohen
}

\section{Abstract}

As part of a cooperative study with the Indiana Department of Environmental Management, the U.S. Geological Survey compiled a computerized data base of nitrate concentrations in Indiana ground water. The data included nitrate determinations from more than 29 studies by five Federal and State agencies during June 1973 through August 1991. The National Water Information System software of the U.S. Geological Survey was used to store the data on a mini-computer at the U.S. Geological Survey office in Indianapolis, Indiana. Electronic data sets were converted to a standard format of well data, sample data, and analytical data. Data were screened by several error-checking procedures before they were retained in the data base. Because the potential existed for a site to be included more than once when overlapping data sets were combined, the data base also was examined for potential duplicates on the basis of well location and name.

The data base of nitrate concentrations in Indiana ground water contains records of 5,525 samples collected from 4,448 wells in 88 of 92 counties during 1973-91. Those wells included 3,832 drinking-water wells; 536 monitoring wells, 38 livestock-supply wells; and 42 irrigation wells. Nitrate concentrations greater than minimum reporting limits of 0.0 to 0.5 milligrams per liter $(\mathrm{mg} / \mathrm{L})$ were determined in 2,453 samples (44 percent of the total). Nitrate in ground water at concentrations greater than $3 \mathrm{mg} / \mathrm{L}$ have been considered to be the result of human activities. Nitrate concentrations ranged from 0.005 to $380 \mathrm{mg} / \mathrm{L}$ with a median nitrate concentration of $0.3 \mathrm{mg} / \mathrm{L}$. Nitrate concentrations were greater than or equal to $3 \mathrm{mg} / \mathrm{L}$ in 704 samples (13 percent of the total). Nitrate concentrations were greater than or equal to the U.S. Environmental Protection Agency Maximum Contaminant Level of $10 \mathrm{mg} / \mathrm{L}$ in 188 samples ( 3.4 percent of the total). Of the 3,832 drinking-water wells in the data base, 147 had at least one sample in which a nitrate concentration was greater than the Maximum Contaminant Level. The percentage of samples with nitrate concentrations greater than or equal to $3 \mathrm{mg} / \mathrm{L}$ and greater than or equal to $10 \mathrm{mg} / \mathrm{L}$ generally increased during the period 1973 through 1991.

The nitrate data base was compiled from numerous data sets that were readily accessible in electronic format. The uses of these data may be limited because they were neither comprehensive nor of a single statistical design. Nonetheless, the nitrate data can be used in several ways: (1) to identify geographic areas with and without nitrate data; (2) to evaluate assumptions, models, and maps of ground-water-contamination potential; and (3) to investigate the relation between environmental factors, land-use types, and the occurrence of nitrate. 


\section{INTRODUCTION}

The Indiana Department of Environmental Management (IDEM), using ground-water contamination records from 1956 through 1989, reported nitrate to be the ground-water contaminant with the highest frequency of occurrence in Indiana (Indiana Department of Environmental Management, 1990, p. 262). The major sources of potential nitrate contamination include septic-system discharges, nitrogen fertilizers, cropland irrigation, livestock and poultry wastes, landfill leachate, industrial wastes, and natural sources in geologic materials or soils (Madison and Brunett, 1985, p. 97-102). Agricultural activities have been documented as the largest nonpoint sources of elevated nitrate concentrations in ground water (Madison and Brunett, 1985, p. 98).

The U.S. Department of Agriculture, Indiana Agricultural Statistics Service (1991, p. 2-3), reported that in 1990 a total of 787 million pounds of nitrogen fertilizer was applied to the 5.6 million acres of corn in Indiana, with an additional 14 million pounds applied to the 4.2 million acres of soybeans in the State. Indiana corn growers applied nitrogen an average of 2.13 times during the growing season - the most often of any State in the nation (U.S. Department of Agriculture, Indiana Agricultural Statistics Service, 1991, p. 2). Nitrogen fertilizer distributed each year in Indiana totals 2.5 million tons, including uses for lawn care and other crops in addition to corn and soybeans (State Nonpoint Source Task Force, 1989, p. 62).

Concern in Indiana about nonpoint-source pollution of ground water with nitrate has been focused primarily on field-applied agricultural fertilizer. The Indiana nonpoint-source waterpollution management program contains a recommendation for "an aggressive groundwater monitoring program to detect harmful levels of nitrate in ground water" and to determine the extent and cause of the problem (State Nonpoint Source Task Force, 1989, p. 62).
The U.S. Geological Survey (USGS) began a cooperative study with the IDEM in 1990 to investigate the relation between environmental and land-use factors and concentrations of agricultural chemicals in Indiana ground water. Part of the project was the compilation of data on pesticide and nitrate concentrations in Indiana ground water. The data on pesticide concentrations in Indiana ground water were summarized by Risch (1994).

\section{PURPOSE AND SCOPE}

This report describes the development of a computerized data base of nitrate concentrations in Indiana ground water and identifies the general objectives, time periods, and methods of the 29 studies by five Federal and State agencies that generated the nitrate determinations. Qualityassurance procedures used in compiling the different data sets are described. Summary statistics for well data, sample data, and analytical data are included for June 1973 through August 1991. The limitations and uses of the nitrate data base are discussed. To expedite the data-compilation and data-entry processes, the IDEM and USGS agreed to include only nitrate data sets that were readily accessible in electronic format. Other determinations of nitrate in Indiana ground water were known to exist, but compilation of these data were beyond the scope of this project.

\section{COMPUTERIZED DATA BASE OF NITRATE CONCENTRATIONS IN INDIANA GROUND WATER}

The USGS National Water Information System (NWIS) was used to create and manage the computer data base for nitrate concentrations in Indiana ground water. 
The primary NWIS data base stores hydrologic and related data on ground- and surface-water sites, streamflow, water quality, and water use. The NWIS has the capability to segregate specialpurpose data sets into alternate data bases. The alternate data bases can be used independently of, and with no affect to, the primary NWIS data base. The nitrate in ground-water data was considered to be special-purpose because of:

(1) the source and brevity of some of the data sets, and

(2) the need to resolve overlapping and duplicate information when different data sets were combined.

Therefore, because of these special purposes and to avoid interference with other uses of the primary data base, the nitrate determinations and associated data were stored in an alternate NWIS data base. Data were stored on a mini-computer in the USGS office in Indianapolis, Ind.

The NWIS software was used to transfer selected information from the primary data base to the alternate data base and to import other electronic data sets into the alternate data base, creating what is called throughout this report the "nitrate data base." The NWIS software also was used to aid in checking all data for errors.

Other advantages of the NWIS are its welldocumented software (Maddy and others, 1989; Mathey, 1989) and its ability to accommodate ancillary information for wells and samples. Ancillary information, such as land use, well depth, aquifer code, and depth to water could be added in the future to help investigate the factors influencing the occurrence of nitrate in Indiana ground water.

\section{Sources of Data}

The nitrate determinations and associated information originated in more than 29 groundwater studies by five government agencies during 1973-91. The time period, number of wells, and number of samples for each of these studies are summarized in table 1 . The sample-collection procedures and analytical methods used for determining nitrate concentrations in these studies were similar and are summarized in table 2. These studies were either localized or statewide in coverage and included water-quality investigations, public-water-supply surveys, rural domestic-well surveys, and water-resource assessments. The following descriptions of the data sources are organized by the type of study and by the agency that directed each study.

\section{Water-Quality Investigations}

The USGS office in Indianapolis, Ind., conducted more than 10 studies from 1973 to 1991 that included the collection and analysis of ground-water samples for nitrate. These studies were of three types:

(1) area-wide or regional water-quality studies, typically covering more than one county;

(2) studies designed to investigate a localized water-quality problem; and

(3) water-quality sampling of a statewide monitoring network.

Generally, USGS studies only involved monitoring wells, but a few studies (such as the herbicides and nitrate reconnaissance) included domestic- and public-supply wells. Detailed information on sample-collection procedures can be found in Wood (1981), Hardy and others (1989), and Kolpin and Burkhart (1991).

Water-quality investigations also were done by Indiana State agencies. The IDEM Ground Water Section collected ground-water samples for determinations of pesticide and nitrate concentrations from domestic-supply wells during 1984-89 as a result of six complaint-response investigations of alleged contamination by agricultural chemicals. During 1988-89, the Indiana Department of Natural Resources (IDNR), Division of Water, collected samples for determining nitrate and other 
Table 1. Sources of information for nitrate data base

[USGS, U.S. Geological Survey; IDEM, Indiana Department of Environmental Management, Ground Water Section; IDNR, Indiana Department of Natural Resources, Division of Water; USEPA, U.S. Environmental Protection Agency; ISBH, Indiana State Board of Health, Public Water Supply Section]

\begin{tabular}{|c|c|c|c|c|}
\hline Agency & Type and name of study & Time period & $\begin{array}{c}\text { Number of } \\
\text { wells }^{\mathrm{a}}\end{array}$ & $\begin{array}{c}\text { Number of } \\
\text { samples }\end{array}$ \\
\hline \multirow[t]{11}{*}{ USGS } & Water-quality investigations & & & \\
\hline & 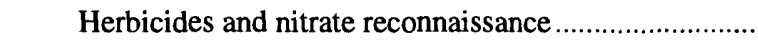 & .. 1989-91 & 52 & 85 \\
\hline & Calumet aquifer study & .. $1986-87$ & 29 & 29 \\
\hline & 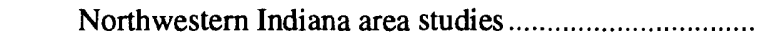 & .. 1973-81 & 110 & 276 \\
\hline & 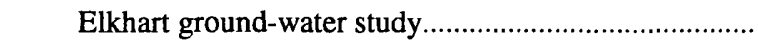 & . $1978-79$ & 108 & 280 \\
\hline & 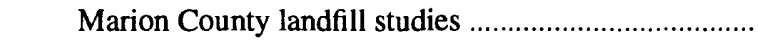 & .. $1973-82$ & 136 & 505 \\
\hline & 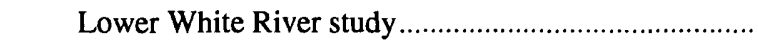 & .. 1980 & 22 & 40 \\
\hline & 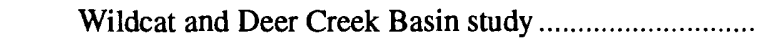 & 1981 & 30 & 31 \\
\hline & 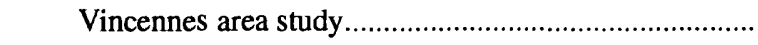 & .. 1976-77 & 21 & 25 \\
\hline & Ground-water monitoring-well network ........................ & .. $1978-90$ & 28 & 31 \\
\hline & 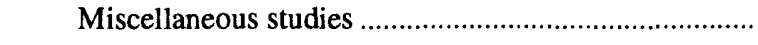 & .. 1973-91 & 37 & 57 \\
\hline IDEM & 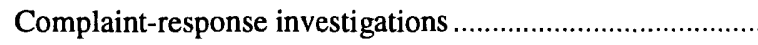 & $\ldots 1984-8931$ & 34 & \\
\hline IDNR & 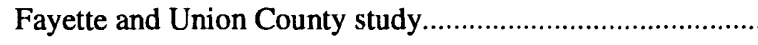 & $\ldots 1988-8928$ & 28 & \\
\hline \multirow[t]{3}{*}{ USEPA } & National survey of pesticides and nitrate in wells: & & & \\
\hline & Public-water supply wells & . $1988-89$ & 10 & 10 \\
\hline & 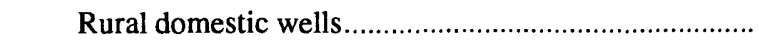 & .. 1989-90 & 41 & 41 \\
\hline USEPA $^{b}$ & 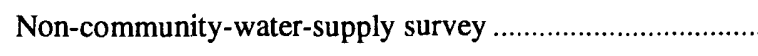 & ... 1983-86 & 2,799 & 2,806 \\
\hline ISBH & Public-water-supply sampling & ... 1975-76 & 133 & 155 \\
\hline IDEM & Public-water-well random survey & $\ldots 1987$ & 57 & 62 \\
\hline IDEM & Vulnerable public-water-well survey & 1988 & 97 & 141 \\
\hline \multirow[t]{7}{*}{ IDEM } & Rural domestic-well surveys & & & \\
\hline & 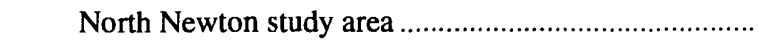 & .. 1988-89 & 27 & 81 \\
\hline & Topeka study area & .. 1989 & 23 & 72 \\
\hline & Lost River study area & 1989 & 16 & 17 \\
\hline & 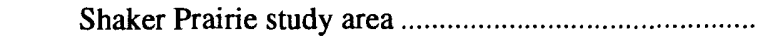 & 1990 & 30 & 33 \\
\hline & Westpoint study area & 1990 & 30 & 33 \\
\hline & 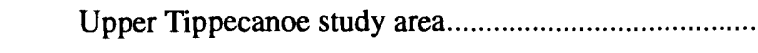 & 1990 & 29 & 33 \\
\hline \multirow[t]{6}{*}{ IDNR } & Water-resource assessments & & & \\
\hline & 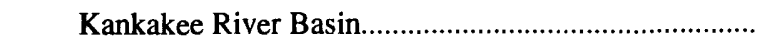 & .. 1985-86 & 244 & 245 \\
\hline & St. Joseph River Basin & .. 1985 & 181 & 181 \\
\hline & 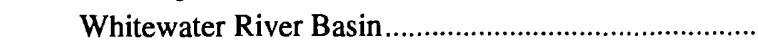 & 1985 & 113 & 115 \\
\hline & 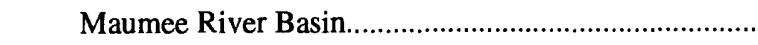 & .. 1988-89 & 33 & 41 \\
\hline & 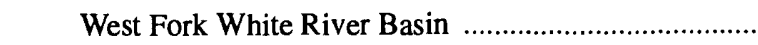 & .. 1989 & 29 & 38 \\
\hline
\end{tabular}

\footnotetext{
${ }^{a}$ Column total will exceed total number of wells in nitrate data base because some wells were used in more than one study.

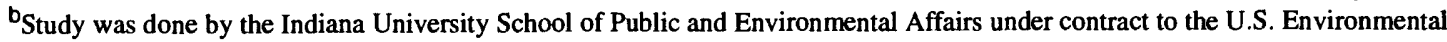
Protection Agency, Region V.
} 
Table 2. Sample-collection procedures and analytical methods

[USGS, U.S. Geological Survey; IDEM, Indiana Department of Environmental Management, Ground Water Section; IDNR, Indiana Department of Natural Resources, Division of Water; USEPA, U.S. Environmental Protection Agency; IUSPEA, Indiana University School of Public and Environmental Affairs; ISBH, Indiana State Board of Health, Public Water Supply Section; IGS, Indiana Geological Survey, Indiana Department of Natural Resources]

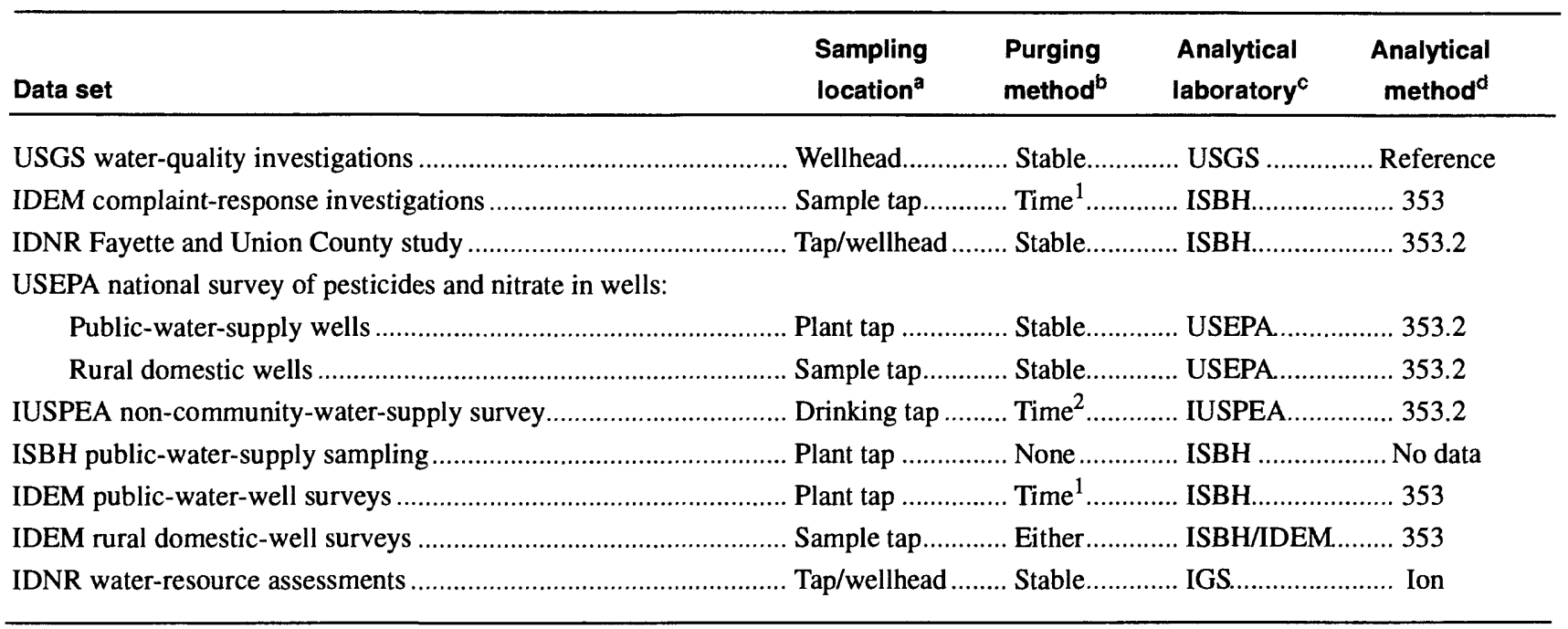

${ }^{\text {a }}$ Sampling location:

Wellhead, sample taken directly from monitoring well;

Sample tap, sample taken from indoor or outdoor cold-water tap before water softener;

Tap/wellhead, sample taken either at cold-water tap before water softener or at wellhead of monitoring well;

Plant tap, sample taken at tap in well house or water-treatment plant;

Drinking tap, sample taken from tap most frequently used for drinking.

${ }^{b}$ Purging method:

Stable, water pumped or bailed from well casing and field measurements of ground-water characteristics

made until values were within approximately $0.1 \mathrm{pH}$ units, 1 degree Celsius of water temperature, and

10 microsiemens per centimeter of specific conductance;

Time $^{1}$, well casing and plumbing purged by letting water flow for 10-15 minutes before sampling;

Time $^{2}$, well casing and plumbing purged by letting water flow 5-7 minutes before sampling;

Either, well casing and plumbing purged by the stable or time ${ }^{1}$ method described.

${ }^{\mathrm{c}}$ Analytical laboratory:

USGS, U.S. Geological Survey, National Water Quality Laboratory in Denver or Atlanta;

ISBH, Indiana State Board of Health Environmental Laboratory;

USEPA, U.S. Environmental Protection Agency, private contract laboratory;

IUSPEA, Indiana University School of Public and Environmental Affairs, private contract laboratory;

IDEM, Indiana Department of Environmental Management, private contract laboratory;

IGS, Indiana Geological Survey, Indiana Department of Natural Resources, Geochemistry Laboratory.

${ }^{\mathrm{d} A n a l y t i c a l ~ m e t h o d: ~}$

Reference, U.S. Geological Survey laboratory method in effect at time of analysis, documented in Skougstad and others (1979) or Fishman and Friedman (1989);

353, U.S. Environmental Protection Agency Method 353, analysis for nitrate plus nitrite as total nitrogen through cadmium reduction with colorimetric detection;

353.2 automated version of U.S. Environmental Protection Agency Method 353;

Ion, analysis for nitrate as total nitrate with a Wescan Ion Analyzer (Tracy Branam, Indiana Geological Survey Geochemistry

Section, oral communication, November 1992). (Any use of trade, product, or firm names in this report is

for descriptive purposes only and does not imply endorsement by the U.S. Government.) 
constituent concentrations during a ground-waterquality evaluation in Fayette and Union Counties in east-central Indiana.

\section{Public-Water-Supply Surveys}

Public-water supplies in Indiana are classified as community-water systems or non-communitywater systems. Community-water systems (CWS) supply 25 or more persons, or at least 15 service connections, for 60 or more consecutive days per year. Non-community-water systems (NCWS) serve 25 or more persons or at least 15 service connections, for less than 60 consecutive days per year. The U.S. Environmental Protection Agency (USEPA) conducted a national survey of pesticides and nitrate in drinking-water wells (U.S. Environmental Protection Agency, 1990); the survey included some public-water-supply wells in Indiana. During 1988-89, as part of the USEPA survey, one CWS in each of 10 Indiana counties was sampled by IDEM staff (Risch, 1994, p. 7) and analyzed at USEPA-contracted laboratories.

The Indiana University School of Public and Environmental Affairs (IUSPEA), under contract with USEPA, Region V, conducted the Indiana non-community-water-supply survey during 1983-86 to inventory and assess water quality of NCWS regulated under the 1974 Federal Safe Drinking Water Act. During the summers of 1983-85, samples from more than 3,200 wells were collected by IUSPEA and analyzed at a private laboratory for total coliform bacteria and nitrate. Details of this study are described in Hunger and others (1986). The IUSPEA's data from the NCWS survey were sent to the USGS in a spreadsheet format on five 3-in. computer discs; however, when compared with the published report by Hunger and others (1986), data for 435 sites in 17 counties were missing. The IUSPEA indicated the missing data were no longer available in electronic format (Dr. William Jones, Indiana University School of Public and Environmental Affairs, oral commun., July 1992); therefore, these data were not included in the nitrate data base (table 3 ).
Table 3. Counties and number of sites from the Indiana non-community-water-supply survey not entered in the nitrate data base

\begin{tabular}{|c|c|}
\hline County & Number of sites \\
\hline Floyd ........ & $\ldots \ldots \ldots$ \\
\hline Fountain.. & $\ldots \ldots$ \\
\hline Franklin... & 23 \\
\hline Fulton...... & .... 33 \\
\hline Gibson.... & $\ldots . .$. \\
\hline Grant ........ & ….......... 37 \\
\hline Greene..... & $\ldots .$. \\
\hline Hamilton & $\ldots \ldots .24$ \\
\hline Hancock. & $\ldots \ldots \ldots .68$ \\
\hline Montgom & ....... 32 \\
\hline Scott ...... & $\ldots .$. \\
\hline Shelby ..... & $\ldots \ldots .46$ \\
\hline Spencer... & $\ldots$ \\
\hline Starke ....... & $\ldots \ldots .44$ \\
\hline Steuben.... & 72 \\
\hline Sullivan .. & $\ldots \ldots$. \\
\hline Switzerlan & ......... 11 \\
\hline
\end{tabular}

Prior to the public-water-supply supervision program of the USEPA under the 1974 Federal Safe Drinking Water Act, the Indiana State Board of Health (ISBH), Public Water Supply Section, collected and analyzed water samples from CWS with water-supply wells (Arnold J. Viere, Indiana State Board of Health, Public Water Supply Section chief, oral commun., January 1993). Analytical data and well information collected by the ISBH from August 1922 through May 1976 were identified in the primary NWIS data base. Paper documentation that would help explain nitrate concentrations in these data were not available in the USGS office in Indianapolis. Historic ISBH files contained documentation of nitrate concentrations only for those samples in the primary NWIS data base that had been collected by the ISBH in 1975 and 1976. Therefore, only data collected by the ISBH in 1975 and 1976 were included in the nitrate data base.

Nitrate determinations from two statewide surveys of pesticides and nitrate in public-watersupply wells were included in the nitrate data base. 
In 1987, the IDEM Ground Water Section in cooperation with USEPA, sampled wells from CWS and NCWS that had been selected by a stratified, random-sample method. In 1988, the IDEM Ground Water Section collected samples from public-water-supply wells that were considered vulnerable to contamination by pesticides. Vulnerability was established by three criteria: (1) a rural location, (2) well completion in unconsolidated materials, and (3) an absence of a significant clay layer above the screened interval (Risch, 1994, p. 4).

\section{Rural Domestic-Well Surveys}

During 1988-90, the IDEM Ground Water Section sampled rural domestic wells in six areas of the State where land use was agricultural and geologic settings were considered vulnerable to contamination by agricultural chemicals. These study areas were named Lost River, North Newton, Shaker Prairie, Topeka, Upper Tippecanoe, and Westpoint (Risch, 1994, p. 4-7). Wells were selected to assess the effects of nonpoint sources of agricultural chemicals (Indiana Department of Environmental Management, 1990, p. 273). Nitrate determinations from samples at these wells were included in the nitrate data base. In another survey of rural domestic wells during 1989-90, USEPA's contractor collected samples from 41 wells in Hancock, Hendricks, Lake, and Marshall Counties as part of the USEPA national survey of pesticides and nitrate in drinking-water wells (Risch, 1994, p. 7).

\section{Water-Resource Assessments}

The Indiana Water Resource Management Act of 1983 required the Indiana Natural Resources Commission to conduct a continuing assessment of water-resource availability in the State (Clendenon and Beaty, 1987, p. 1). In 1985, the IDNR, acting as the technical staff for the Commission, began a series of investigations to characterize ground- and surface-water resources throughout Indiana. During the assessments, the IDNR collected ground-water samples for determination of nitrate and other constituent concentrations. The samples were from wells thought to be unaffected by contaminant sources (Judith Beaty, Indiana Department of Natural Resources, Basin Studies Section chief, oral commun., March 1991). Data from assessments of five basins completed from 1985 to 1989 were included in the nitrate data base. Nitrate determinations from 79 samples collected in the Maumee River Basin and West Fork White River Basin water-resource assessments were transferred from the primary NWIS data base to the nitrate data base. In addition, nitrate determinations from 541 samples collected in the Kankakee River, St. Joseph River, and Whitewater River Basins were obtained from IDNR in electronic format and entered in the nitrate data base.

\section{Well and Sample Data}

Data for each well entered into the nitrate data base included location information, identification designation, name, use of the well, and use of the water. Data for each sample included collection date and time, collecting agency, analyzing agency, and analytical results. Location data included latitude, longitude, and county. Data obtained from all sources except the IDNR included the degrees, minutes, and seconds of latitude and longitude for each well. All the data obtained from the IDNR had well locations according to the Universal Transverse Mercator grid system. These locations were converted to latitude and longitude by use of the ARC/NFO ${ }^{1}$ computer software (Environmental Systems Research Institute, Inc., 1989).

For the nitrate data base, each well was assigned a unique 20-character identification designation (ID); for example, IN033404425084561601. The first five characters of the ID (for example, IN033) are an alphanumeric code to identify the agency or organization from which the data were obtained. The next 13 numeric characters

${ }^{1}$ Any use of trade product, or firm names in this report is for descriptive purposes only and does not imply endorsement by the U.S. Government. 
were typically the latitude (for example, 404425) and the longitude (for example, 0845616) of the well. The last two characters (for example, 01) were a numeric-sequence number used to distinguish between two or more wells with the same latitude and longitude. Each well had a name of up to 50 characters. The CWS and NCWS wells usually were identified with the name of the facility. Domestic wells usually were described by mailing address or roads and landmarks. The USGS monitoring wells typically were named with a project-related alphanumeric code. Wells were either monitoring wells or withdrawal wells. Water at monitoring wells was classified as unused.

Water use at withdrawal wells was classified in one of the following categories: commercial, institutional, irrigation, industrial, public supply, livestock, or domestic. Each of these water-use categories is explained in detail in Mathey (1989, p. 2-30 to 2-32).

Data associated with each ground-water sample were identified uniquely by a combination of the ID for the well from which the water sample was collected; the date the sample was collected; and, if available, the time the sample was collected. Distinct five-digit parameter codes were used in the data base to store the name of the agency that collected the sample, the name of the agency laboratory that analyzed the sample, and the concentration of each nitrate analyte in the sample (table 4). All analyte concentrations were entered as milligrams per liter $(\mathrm{mg} / \mathrm{L})$. For two of the parameter codes, for the agency collecting the sample, and for the agency analyzing the sample, the name of the specific agency was represented by a fixedvalue code (table 5).

\section{Quality-Assurance Procedures}

All data were entered by use of two subsystems of the NWIS - the Ground-Water Site Inventory System (GWSI) and the Water-Quality System (QWDATA). The GWSI is a ground-waterdata storage and retrieval system that was used for entering well information such as location, name, well use, and water use. The QWDATA is a water-
Table 4. Descriptions of five-digit parameter codes

\begin{tabular}{cl}
\hline Parameter code & \multicolumn{1}{c}{ Description } \\
\hline 00027 & Agency collecting sample \\
00028 & Agency analyzing sample \\
00618 & $\begin{array}{c}\text { Concentration of nitrate as nitrogen, } \\
\text { determined from a filtered sample }\end{array}$ \\
00620 & $\begin{array}{c}\text { Concentration of nitrate as nitrogen, } \\
\text { determined from an unfiltered sample }\end{array}$ \\
00630 & $\begin{array}{c}\text { Concentration of nitrate + nitrite as } \\
\text { nitrogen, determined from an } \\
\text { unfiltered sample }\end{array}$ \\
00631 & $\begin{array}{c}\text { Concentration of nitrate + nitrite as } \\
\text { nitrogen, determined from a filtered } \\
\text { sample }\end{array}$ \\
\hline
\end{tabular}

Table 5. Descriptions of fixed-value codes for collecting and analyzing agency

\begin{tabular}{|c|c|}
\hline Fixed-value code & Description \\
\hline 1028 & U.S. Geological Survey \\
\hline 2000 & U.S. Environmental Protection Agency \\
\hline 9718 & Indiana State Board of Health \\
\hline 18001 & $\begin{array}{l}\text { Indiana Department of Environmental } \\
\text { Management }\end{array}$ \\
\hline 18003 & $\begin{array}{l}\text { Indiana Geological Survey, Department of } \\
\text { Natural Resources }\end{array}$ \\
\hline 18004 & $\begin{array}{l}\text { Indiana Department of Natural Resources, } \\
\text { Division of Water }\end{array}$ \\
\hline 18007 & $\begin{array}{l}\text { Indiana University School of Public and } \\
\text { Environmental Affairs }\end{array}$ \\
\hline 80010 & $\begin{array}{l}\text { U.S. Geological Survey, National Water } \\
\text { Quality Laboratory-Atlanta }\end{array}$ \\
\hline 80020 & $\begin{array}{l}\text { U.S. Geological Survey, National Water } \\
\text { Quality Laboratory-Denver }\end{array}$ \\
\hline 99001 & Private contract laboratory \\
\hline
\end{tabular}


quality-data storage and retrieval system that was used to enter sample information such as collection dates and times, name of collecting and analyzing agency, and analytical results. Data from the ISBH, USGS, IDNR, and IDEM already in the primary NWIS data base at the inception of this project were retrieved and entered into the nitrate data base by use of GWSI and QWDATA. Additional data from the IDNR on magnetic tape and data from the IUSPEA on 3-in. computer discs were converted into GWSI and QWDATA formats by computer programs written in FORTRAN 77 code.

All data entered through GWSI and QWDATA were screened by a number of automatic, error-checking procedures. The GWSI error checks included rejection of invalid character types, rejection of duplicate 20-character IDs, rejection of latitudes and longitudes outside Indiana, and flagging of latitudes and longitudes outside the ranges for those of the specified county. The QWDATA error checks included rejection of invalid character types and rejection of any sample data for a given well with duplicate collection dates and times.

All location information provided by each source agency was assumed to be correct unless the latitudes or longitudes were rejected or flagged by the error-checking procedures in GWSI. If a well had a latitude or longitude rejected or flagged, an attempt was made to obtain accurate location information by contacting the well owner. If the owner could not be contacted, the local branch of the U.S. Postal Service was requested to provide a location description based on the mailing address. If sufficient location information was obtained, the well was plotted on a 7.5-minute topographic map, the latitude and longitude were determined, and the data for that well were entered into the NWIS. If sufficient location information could not be obtained from the owner or the Postal Service, the well and associated data were not entered.

Although the GWSI automatically checked new ID's (typically containing the latitude and longitude of a well) to avoid entering an ID already in the data base, additional potential for duplicate wells existed because data sets from different agencies were combined. For example, a duplicate could be the same well in two data sets from different agencies, only with a latitude or longitude that differed by one second. Therefore, after all wells were entered into the nitrate data base, an additional search was made for potential duplicates on the basis of (a) a difference of 5 seconds or less in latitude or longitude, and (b) identical or very similar names. To reconcile duplicates, written documentation in files or published reports were reviewed, well depths and location data were examined, and sample dates and times were compared. If two or more ID's were determined to represent the same well, the ID for the well with better documentation and/or more ancillary data was retained, the remaining site(s) were deleted, and sample data for deleted ID's were transferred to the one retained in the nitrate data base.

\section{Descrlptlve Statlstlcs}

Descriptive statistics for the data include summary information about wells and samples, nitrate analytes, and nitrate detections. Nitrate detections are discussed in reference to reporting limits, concentration ranges, and regulatory concentration limits.

\section{Wells and Samples}

The nitrate data base contains records for 5,525 samples collected from 4,448 wells during June 1973 through August 1991. Of the total number of samples, 2,806 (51 percent) were from the Indiana non-community-water-supply survey by the IUSPEA during 1983-85. Other samples were in data sets obtained from the USGS (25 percent), the IDNR (12 percent), and the IDEM (9.2 percent). The types of wells include 536 monitoring wells and 3,912 water-supply wells. Among the water-supply wells, 248 were from CWS; 2,844 were from NCWS; 740 were domestic supplies; 42 were irrigation supplies; and 38 were livestock supplies. Eighty-six percent $(3,832)$ of all wells sampled were drinking-watersupply wells. Ground-water samples analyzed for nitrate were from wells in 88 of the 92 counties in Indiana (table 6). Fourteen counties had greater 
Table 6. Number of wells and samples per county in the nitrate data base [FIPS, Federal Information Processing System three-digit code for county]

\begin{tabular}{|c|c|c|c|c|c|}
\hline County name & FIPS code & Samples & County name & FIPS code & Samples \\
\hline Adams & $001 \ldots \ldots \ldots \ldots \ldots \ldots . . . . . . . .62$ & 64 & Lawrence & $093 \ldots \ldots \ldots \ldots \ldots . . \quad 2$ & 2 \\
\hline Allen & $003 \ldots \ldots \ldots \ldots \ldots . . . . . . . . .142$ & 149 & Madison & $095 \ldots \ldots \ldots \ldots \ldots \ldots$ & 100 \\
\hline Bartholemew & $005 \ldots \ldots \ldots \ldots \ldots \ldots . . . . . . . . .29$ & 38 & Marion & $097 \ldots \ldots \ldots \ldots \ldots \ldots . . . . . . . . .13$ & 693 \\
\hline Benton & $007 \ldots \ldots \ldots \ldots \ldots . . . . . . . .16$ & 16 & Marshall & $099 \ldots \ldots \ldots \ldots \ldots . . .121$ & 124 \\
\hline Blackford & $009 \ldots \ldots \ldots \ldots \ldots \ldots . \ldots . \ldots . \ldots . \ldots$ & 21 & Martin & $101 \ldots \ldots \ldots \ldots \ldots \ldots \ldots$ & 5 \\
\hline Boone & $011 \ldots \ldots \ldots \ldots \ldots . . . .27$ & 28 & Miami & $103 \ldots \ldots \ldots \ldots \ldots . . . . .27$ & 28 \\
\hline Brown & $013 \ldots \ldots \ldots \ldots \ldots \ldots . . . . . . . \quad 0$ & 0 & Monroe & $105 \ldots \ldots \ldots \ldots \ldots \ldots . . \quad 5$ & 5 \\
\hline Carroll & $015 \ldots \ldots \ldots \ldots \ldots \ldots$ & 39 & Montgomery & $107 \ldots \ldots \ldots \ldots \ldots \ldots \ldots$ & 7 \\
\hline Cass & $017 \ldots \ldots \ldots \ldots \ldots . . . .42$ & 42 & Morgan & $109 \ldots \ldots \ldots \ldots \ldots \ldots . . .54$ & 75 \\
\hline Clark & $019 \ldots \ldots \ldots \ldots \ldots \ldots$ & 5 & Newton & $111 \ldots \ldots \ldots \ldots \ldots \ldots . . .94$ & 157 \\
\hline Clay & $021 \ldots \ldots \ldots \ldots \ldots \ldots$ & 27 & Noble & $113 \ldots \ldots \ldots \ldots \ldots \ldots . .150$ & 185 \\
\hline Clinton & $023 \ldots \ldots \ldots \ldots \ldots \ldots$ & 36 & Ohio & $115 \ldots \ldots \ldots \ldots \ldots \ldots \ldots$ & 1 \\
\hline Crawford & $025 \ldots \ldots \ldots \ldots \ldots \ldots . . . \quad 4$ & 4 & Orange & $117 \ldots \ldots \ldots \ldots \ldots \ldots . . . .22$ & 29 \\
\hline Daviess & $027 \ldots \ldots \ldots \ldots \ldots \ldots . . . . .16$ & 17 & Owen & $119 \ldots \ldots \ldots \ldots \ldots \ldots \ldots$ & 33 \\
\hline Dearborn & $029 \ldots \ldots \ldots \ldots \ldots \ldots . . . . .6$ & 8 & Parke & $121 \ldots \ldots \ldots \ldots \ldots . . . . . . . .30$ & 33 \\
\hline Decatur & $031 \ldots \ldots \ldots \ldots \ldots . . . .33$ & 36 & Perry & $123 \ldots \ldots \ldots \ldots \ldots \ldots$ & 9 \\
\hline Dekalb & $033 \ldots \ldots \ldots \ldots \ldots . . . . . . .46$ & 49 & Pike & $125 \ldots \ldots \ldots \ldots \ldots \ldots \ldots$ & 5 \\
\hline Delaware & $035 \ldots \ldots \ldots \ldots \ldots \ldots . . . . . . . .93$ & 94 & Porter & $127 \ldots \ldots \ldots \ldots \ldots \ldots . . . . .208$ & 344 \\
\hline Dubois & $037 \ldots \ldots \ldots \ldots \ldots \ldots . . . . . .1$ & 2 & Posey & $129 \ldots \ldots \ldots \ldots \ldots \ldots$ & 20 \\
\hline Elkhart & $039 \ldots \ldots \ldots \ldots \ldots \ldots . . . . . . . . . .316$ & 502 & Pulaski & $131 \ldots \ldots \ldots \ldots \ldots \ldots . . . . . . .40$ & 42 \\
\hline Fayette & $041 \ldots \ldots \ldots \ldots \ldots \ldots . . . . . . .55$ & 58 & Putnam & $133 \ldots \ldots \ldots \ldots \ldots . . . . . . .25$ & 30 \\
\hline Floyd & $043 \ldots \ldots \ldots \ldots \ldots \ldots . . . . . . . . \quad 0$ & 0 & Randolph & $135 \ldots \ldots \ldots \ldots \ldots \ldots . . . . . .52$ & 54 \\
\hline Fountain & $045 \ldots \ldots \ldots \ldots \ldots \ldots . .3$ & 5 & Ripley & $137 \ldots \ldots \ldots \ldots \ldots \ldots \ldots$ & 13 \\
\hline Franklin & $047 \ldots \ldots \ldots \ldots \ldots \ldots$ & 19 & Rush & $139 \ldots \ldots \ldots \ldots \ldots . . . . . . . .39$ & 42 \\
\hline Fulton & $049 \ldots \ldots \ldots \ldots \ldots . . . . . . . . \quad 0$ & 0 & St. Joseph & $141 \ldots \ldots \ldots \ldots \ldots . . . .144$ & 145 \\
\hline Gibson & $051 \ldots \ldots \ldots \ldots \ldots \ldots$ & 16 & Scott & $143 \ldots \ldots \ldots \ldots \ldots$ & 0 \\
\hline Grant & $053 \ldots \ldots \ldots \ldots \ldots \ldots$ & 11 & Shelby & $145 \ldots \ldots \ldots \ldots \ldots \ldots$ & 3 \\
\hline Greene & $055 \ldots \ldots \ldots \ldots \ldots \ldots . \quad 2$ & 4 & Spencer & $147 \ldots \ldots \ldots \ldots \ldots \ldots \ldots \ldots$ & 5 \\
\hline Hamilton & $057 \ldots \ldots \ldots \ldots \ldots \ldots . . .11$ & 14 & Starke & $149 \ldots \ldots \ldots \ldots \ldots . . .19$ & 19 \\
\hline Hancock & $059 \ldots \ldots \ldots \ldots \ldots \ldots$ & 17 & Steuben & $151 \ldots \ldots \ldots \ldots \ldots . . .47$ & 49 \\
\hline Harrison & $061 \ldots \ldots \ldots \ldots \ldots \ldots . . \quad 5$ & 6 & Sullivan & $153 \ldots \ldots \ldots \ldots \ldots . . .24$ & 31 \\
\hline Hendricks & $063 \ldots \ldots \ldots \ldots \ldots \ldots . . . . . . .90$ & 90 & Switzerland & $155 \ldots \ldots \ldots \ldots \ldots \ldots . . .1$ & 2 \\
\hline Henry & $065 \ldots \ldots \ldots \ldots \ldots \ldots$ & 60 & Tippecanoe & $157 \ldots \ldots \ldots \ldots \ldots \ldots . . . . . .116$ & 121 \\
\hline Howard & $067 \ldots \ldots \ldots \ldots \ldots \ldots . . . .50$ & 51 & Tipton & $159 \ldots \ldots \ldots \ldots \ldots \ldots \ldots$ & 25 \\
\hline Huntington & $069 \ldots \ldots \ldots \ldots \ldots \ldots$ & 19 & Union & $161 \ldots \ldots \ldots \ldots \ldots \ldots . . . . .40$ & 42 \\
\hline Jackson & $071 \ldots \ldots \ldots \ldots \ldots \ldots . . . .31$ & 41 & Vanderburgh & $163 \ldots \ldots \ldots \ldots \ldots \ldots \ldots$ & 9 \\
\hline Jasper & $073 \ldots \ldots \ldots \ldots \ldots \ldots . . .136$ & 143 & Vermillion & $165 \ldots \ldots \ldots \ldots \ldots \ldots$ & 21 \\
\hline Jay & $075 \ldots \ldots \ldots \ldots \ldots \ldots . . .20$ & 20 & Vigo & $167 \ldots \ldots \ldots \ldots \ldots \ldots .62$ & 64 \\
\hline Jefferson & $077 \ldots \ldots \ldots \ldots \ldots \ldots \ldots$ & 8 & Wabash & $169 \ldots \ldots \ldots \ldots \ldots . .27$ & 29 \\
\hline Jennings & $079 \ldots \ldots \ldots \ldots \ldots \ldots \ldots$ & 3 & Warren & $171 \ldots \ldots \ldots \ldots \ldots . .20$ & 24 \\
\hline Johnson & $081 \ldots \ldots \ldots \ldots \ldots \ldots . . . .43$ & 52 & Warrick & $173 \ldots \ldots \ldots \ldots \ldots \ldots . .6$ & 9 \\
\hline Knox & $083 \ldots \ldots \ldots \ldots \ldots \ldots$ & 65 & Washington & $175 \ldots \ldots \ldots \ldots \ldots \ldots$ & 15 \\
\hline Kosciusko & $085 \ldots \ldots \ldots \ldots \ldots \ldots . . .204$ & 212 & Wayne & $177 \ldots \ldots \ldots \ldots \ldots \ldots . . .136$ & 137 \\
\hline LaGrange & $087 \ldots \ldots \ldots \ldots \ldots \ldots . . .153$ & 178 & Wells & $179 \ldots \ldots \ldots \ldots \ldots \ldots \ldots$ & 24 \\
\hline Lake & $089 \ldots \ldots \ldots \ldots \ldots \ldots . . . . . . . .152$ & 172 & White & $181 \ldots \ldots \ldots \ldots \ldots . . . . .78$ & 81 \\
\hline LaPorte & $091 \ldots \ldots \ldots \ldots \ldots . . .135$ & 153 & Whitley & $183, \ldots \ldots \ldots \ldots \ldots \ldots$ & 40 \\
\hline
\end{tabular}


than 100 wells sampled and 25 counties had less than 10 wells sampled. The counties with the largest number of wells sampled were Elkhart (316), Marion (313), Porter (208), and Kosciusko (204). Determinations of nitrate concentrations in ground-water samples collected between 1973 and 1991 are stored in the data base; 3,979 of the samples (72 percent) were from 1983 through 1989 , and 1,357 samples ( 25 percent) were from 1973 through 1982.

\section{Nitrate Analytes}

The nitrate data base contains the results of 6,593 individual determinations for a nitrate analyte; 1,068 of the samples (19 percent) contained determinations for both nitrate as nitrogen $\left(\mathrm{NO}_{3}-\mathrm{N}\right)$ and nitrate plus nitrite as nitrogen $\left[\left(\mathrm{NO}_{3}+\mathrm{NO}_{2}\right)-\mathrm{N}\right]$ and 1,081 samples ( 20 percent) contained a determination only for $\left(\mathrm{NO}_{3}+\mathrm{NO}_{2}\right)-\mathrm{N}$. The distribution of nitrate-analyte determinations among the 5,525 samples is shown in table 7. The samples with only $\left(\mathrm{NO}_{3}+\mathrm{NO}_{2}\right)-\mathrm{N}$ determinations were examined for accompanying data on nitrite as nitrogen $\left(\mathrm{NO}_{2}-\mathrm{N}\right)$ to ascertain if nitrate concentrations in all 5,525 samples could be discussed in terms of $\mathrm{NO}_{3}-\mathrm{N}$.

Of the 1,081 samples in the nitrate data base with only a $\left(\mathrm{NO}_{3}+\mathrm{NO}_{2}\right)-\mathrm{N}$ determination, sulfuric acid was used as the preservative for 829 samples (Indiana Department of Environmental Management, written commun.; Hunger and others, 1986). During 1992-93, staff from the USGS National Water Quality Laboratory conducted an experiment in which it was shown that preservation of samples with sulfuric acid systematically destroyed $\mathrm{NO}_{2}-\mathrm{N}$ in all samples (Iris Collies, U.S. Geological Survey, written commun., 1994). Sulfuric acid was not used to preserve 252 samples in the nitrate data base with only a $\left(\mathrm{NO}_{3}+\mathrm{NO}_{2}\right)-\mathrm{N}$ determination. Of these 252 samples, the $\left(\mathrm{NO}_{3}+\mathrm{NO}_{2}\right)-\mathrm{N}$ concentration was less than the reporting limit for 73 samples, indicating $\mathrm{NO}_{2}-\mathrm{N}$ was not present. The $\mathrm{NO}_{2}-\mathrm{N}$ concentration was available from the primary data base for 179 of the 252 samples in which $\left(\mathrm{NO}_{3}+\mathrm{NO}_{2}\right)-\mathrm{N}$ was detected. The $\mathrm{NO}_{2}-\mathrm{N}$ concentration in these 179 samples was less than or equal to $0.01 \mathrm{mg} / \mathrm{L}$. In a related observation, $\operatorname{Hem}\left(1989\right.$, p. 124) reported that $\mathrm{NO}_{2}-\mathrm{N}$ is seldom present in concentrations large enough to influence the ionic balance of nitrogen species in natural waters. Therefore, in this report, the $\mathrm{NO}_{2}-\mathrm{N}$ concentrations in the 1,081 samples with only $\left(\mathrm{NO}_{3}+\mathrm{NO}_{2}\right)-\mathrm{N}$ determinations are considered to be negligible, and "nitrate" in all 5,525 samples is discussed as $\mathrm{NO}_{3}-\mathrm{N}$.

The number of filtered samples was less than the number of unfiltered samples because the USGS was the only collecting agency that filtered ground-water samples intended for nitrate analysis. The USGS samples were passed through a 0.45 -micrometer pore-size filter before being placed in the samples containers and sent to the laboratory.

\section{Nitrate Detectlons}

The 10 different minimum reporting limits for nitrate analytes combined from all the samples are listed in table 8. The minimum reporting limit is the smallest concentration reported by the laboratory; a nondetection of a nitrate analyte was a concentration less than the minimum reporting limit. The minimum reporting limits ranged from 0.0 to $0.5 \mathrm{mg} / \mathrm{L}$, and the smallest concentration detected was $0.005 \mathrm{mg} / \mathrm{L}$.

Table 7. Distribution of samples and nitrate-analyte determinations in the nitrate data base [NO $-\mathrm{N}$, nitrate as nitrogen; $\left(\mathrm{NO}_{3}+\mathrm{NO}_{2}\right)-\mathrm{N}$, nitrate plus nitrite as nitrogen]

\begin{tabular}{|c|c|c|}
\hline Flltered samples & Unfiltered samples & Total \\
\hline 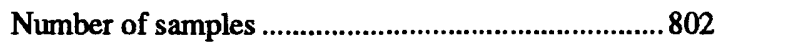 & 4,723 & 5,525 \\
\hline 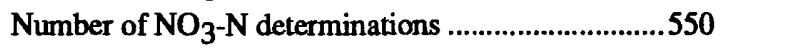 & 3,894 & 4,444 \\
\hline Number of $\left(\mathrm{NO}_{3}+\mathrm{NO}_{2}\right)$ - $\mathrm{N}$ determinations................802 & 1,347 & 2,149 \\
\hline
\end{tabular}


Table 8. Number of nitrate-analyte determinations per minimum reporting limit

[Minimum reporting limits are concentrations in milligrams per liter; $\mathrm{NO}_{3}-\mathrm{N}$, nitrate as nitrogen; $\left(\mathrm{NO}_{3}+\mathrm{NO}_{2}\right)-\mathrm{N}$, nitrate plus nitrite as nitrogen]

\begin{tabular}{|c|c|c|c|c|}
\hline \multirow{2}{*}{$\begin{array}{l}\text { Minimum } \\
\text { reporting } \\
\text { limit }\end{array}$} & \multicolumn{2}{|c|}{ Filtered samples } & \multicolumn{2}{|c|}{ Unfiltered samples } \\
\hline & $\mathrm{NO}_{3}$ & $\left.\mathrm{O}_{3}+\mathrm{NO}_{2}\right)-\mathrm{N}$ & $\mathrm{NO}_{3}-\mathrm{N}$ & $\left(\mathrm{NO}_{3}+\mathrm{NO}_{2}\right)-\mathrm{N}$ \\
\hline 0.0 & 123 & 0 & 50 & 0 \\
\hline 0.005 & 0 & 3 & 0 & 0 \\
\hline 0.01 & 0 & 44 & 0 & 36 \\
\hline 0.02 & 0 & 0 & 396 & 0 \\
\hline 0.05 & 0 & 23 & 0 & 0 \\
\hline 0.10 & 0 & 96 & 15 & 281 \\
\hline 0.15 & 0 & 0 & 0 & 16 \\
\hline 0.20 & 0 & 0 & 1 & 0 \\
\hline 0.30 & 0 & 0 & 2,074 & 22 \\
\hline 0.50 & 0 & 0 & 32 & 0 \\
\hline
\end{tabular}

The number of nitrate-concentration values for 12 concentration ranges are shown in table 9. One nitrate determination per sample is presented, including $\mathrm{NO}_{3}-\mathrm{N}$ concentrations from 4,444 samples and $\left(\mathrm{NO}_{3}+\mathrm{NO}_{2}\right)-\mathrm{N}$ concentrations from 1,081 samples. Nitrate was detected-that is, the concentration was greater than a minimum reporting limit-in 2,453 of the 5,525 samples (44 percent). The median nitrate concentration was $0.3 \mathrm{mg} / \mathrm{L}$. Nitrate in ground water at concentrations greater than $3 \mathrm{mg} / \mathrm{L}$ generally are considered to be the result of human activities (Bachman, 1984, p. 14; Hamilton and others, 1989, p. 44; Madison and Brunett, 1985, p. 94). Nitrate concentrations were greater than or equal to $3 \mathrm{mg} / \mathrm{L}$ in 704 samples in the nitrate data base (13 percent of the total).

The USEPA (U.S. Environmental Protection Agency, 1992) has established a Maximum Contaminant Level (MCL) of $10 \mathrm{mg} / \mathrm{L}$ for $\mathrm{NO}_{3}-\mathrm{N}$ and $\left(\mathrm{NO}_{3}+\mathrm{NO}_{2}\right)-\mathrm{N}$. The $\mathrm{MCL}$ is the largest concentration permissible in the treated water delivered to
Table 9. Number of nitrate-concentration values per concentration range

[Concentration range in milligrams per liter]

\begin{tabular}{ccccc}
\hline $\begin{array}{c}\text { Concentration } \\
\text { range }\end{array}$ & $\begin{array}{c}\text { Filtered } \\
\text { samples }\end{array}$ & $\begin{array}{c}\text { Unfiltered } \\
\text { samples }\end{array}$ & $\begin{array}{c}\text { All } \\
\text { samples }\end{array}$ \\
\hline $0.005-0.99$ & 418 & 918 & 1,336 \\
$1.00-2.99$ & 69 & 344 & 413 \\
$3.0-4.99$ & 53 & 186 & 239 \\
$5.00-$ & -9.99 & 56 & 221 & 277 \\
10 & -14.9 & 7 & 107 & 114 \\
15 & -19.9 & 2 & 36 & 38 \\
20 & -24.9 & 1 & 16 & 17 \\
25 & -29.9 & 0 & 7 & 7 \\
30 & -39.9 & 0 & 4 & 4 \\
40 & -79.9 & 0 & 4 & 4 \\
80 & -149.9 & 0 & 2 & 2 \\
$150.0-380.0$ & 0 & 2 & 2 \\
\hline
\end{tabular}

customers of public-water supplies, both CWS and NCWS. Although the MCL is not legally applicable to water from wells that are not part of a public-water supply, concentrations of nitrate in excess of $10 \mathrm{mg} / \mathrm{L}$ commonly are considered to be an indication of contamination (Madison and Brunett, 1985, p. 93). Of the 5,525 samples, 188 samples ( 3.4 percent) contained a nitrate concentration greater than or equal to $10 \mathrm{mg} / \mathrm{L}$. These samples had concentrations ranging from 10 to $380 \mathrm{mg} / \mathrm{L}$-only 4 concentrations exceeded $80 \mathrm{mg} / \mathrm{L}$ and 152 of the 188 were less than $20 \mathrm{mg} / \mathrm{L}$. Of the 188 ground-water samples with nitrate concentrations greater than or equal to the MCL, 173 were from 147 drinking-water-supply wells. Figure 1 shows the locations of the 147 drinking-water-supply wells that had at least one nitrate concentration greater than or equal to $10 \mathrm{mg} / \mathrm{L}$. Counties with the largest numbers of drinking-water wells with a sample in which the nitrate MCL was equalled or exceeded include LaGrange (17), Kosciusko (13), and Sullivan (12). 
The nitrate data base is a compilation of numerous data sets lacking a common design for determining trends in nitrate concentrations. Observations, however, were made regarding the percentage of samples per 4- or 5-year time period with nitrate concentrations that were equal to or greater than $3 \mathrm{mg} / \mathrm{L}$ and equal to or greater than $10 \mathrm{mg} / \mathrm{L}$ (fig. 2). From 1973 to 1991, the percentage of samples in both concentration groups generally increased.

\section{LIMITATIONS AND USES OF THE NITRATE DATA BASE}

The nitrate data base has inherent limitations because it was compiled from more than 29 data sets collected for different purposes by five Federal and State agencies and their contractors over a 19-year period. The sample-collection and analytical methods were generally similar among these data; however, the minimum reporting limits were not the same for all nitrate-analyte determinations in all studies. Other data sources with nitrate concentrations for Indiana ground water were known to exist, but inclusion of those data was beyond the scope of the project described in this report. Therefore, conclusions about the occurrence or sources of nitrate in ground water statewide were not possible.

Although the nitrate data base has limitations because it was neither comprehensive nor based on a single statistical design, it can be beneficial in several ways.

(1) The data base contains a geographic distribution of historical nitrate data and thus enables the identification of areas where data are present or absent.

(2) The nitrate data could be used to evaluate the assumptions, models, and maps of ground-water-contamination potential that are tools in regional and statewide planning.
(3) The nitrate data can be used in a geographic-information system to investigate the relation between environmental factors, land-use types, and concentrations of nitrate.

\section{SUMMARY}

Nitrate has been reported as the most frequently occurring contaminant of Indiana ground water. Nitrate in ground water can originate from septic systems, fertilizers, irrigation, livestock wastes, landfills, and some natural sources. Agricultural activities have been documented as the largest nonpoint sources of elevated nitrate concentrations in ground water.

In a cooperative study with the IDEM to investigate the occurrence of agricultural chemicals in Indiana ground water, the USGS compiled a computerized data base of nitrate concentrations from data that were readily available in electronic format. Sources of the data were more than 29 studies by five Federal and State agencies. The USGS National Water Information System software was used to convert the electronic data sets to a standard format of well data, sample data, and analytical data. Data were screened by several error-checking procedures and examined for potential duplicates before they were retained in the nitrate data base.

The nitrate data base contains records of 5,525 samples collected during 1973-91 from 3,832 drinking-water-supply wells; 536 monitoring wells; 38 livestock-supply wells; and 42 irrigation wells in 88 of the 92 counties in Indiana. The samples were collected in a similar manner and the nitrate analyses were made by comparable methods. Concentrations of nitrate greater than minimum reporting limits of 0.0 to $0.5 \mathrm{mg} / \mathrm{L}$ occurred in 44 percent of all samples and ranged in value from 0.005 to $380 \mathrm{mg} / \mathrm{L}$. Scientists generally consider concentrations of nitrate in ground water greater than $3 \mathrm{mg} / \mathrm{L}$ to be the result of human activities; 13 percent of the concentrations in the nitrate data base were greater than or 
equal to $3 \mathrm{mg} / \mathrm{L}$. Concentrations of nitrate greater than or equal to the $\mathrm{MCL}$ of $10 \mathrm{mg} / \mathrm{L}$ were present in 147 of the 3,832 drinking-water wells in the data base. The percentage of samples containing nitrate concentrations equal to or greater than $3 \mathrm{mg} / \mathrm{L}$ and equal to or greater than $10 \mathrm{mg} / \mathrm{L}$ generally increased from 1973 through 1991.

The nitrate data base combined data from different sources and did not possess a common statistical design. Therefore, conclusions about the occurrence or sources of nitrate in ground water statewide were not possible. The nitrate data, however, can be used in several ways: for identification of geographic areas with and without nitrate data; in the evaluation of assumptions, models, and maps of ground-water-contamination potential; and in the investigation of the relation between environmental factors, land-use types, and the occurrence of nitrate. 


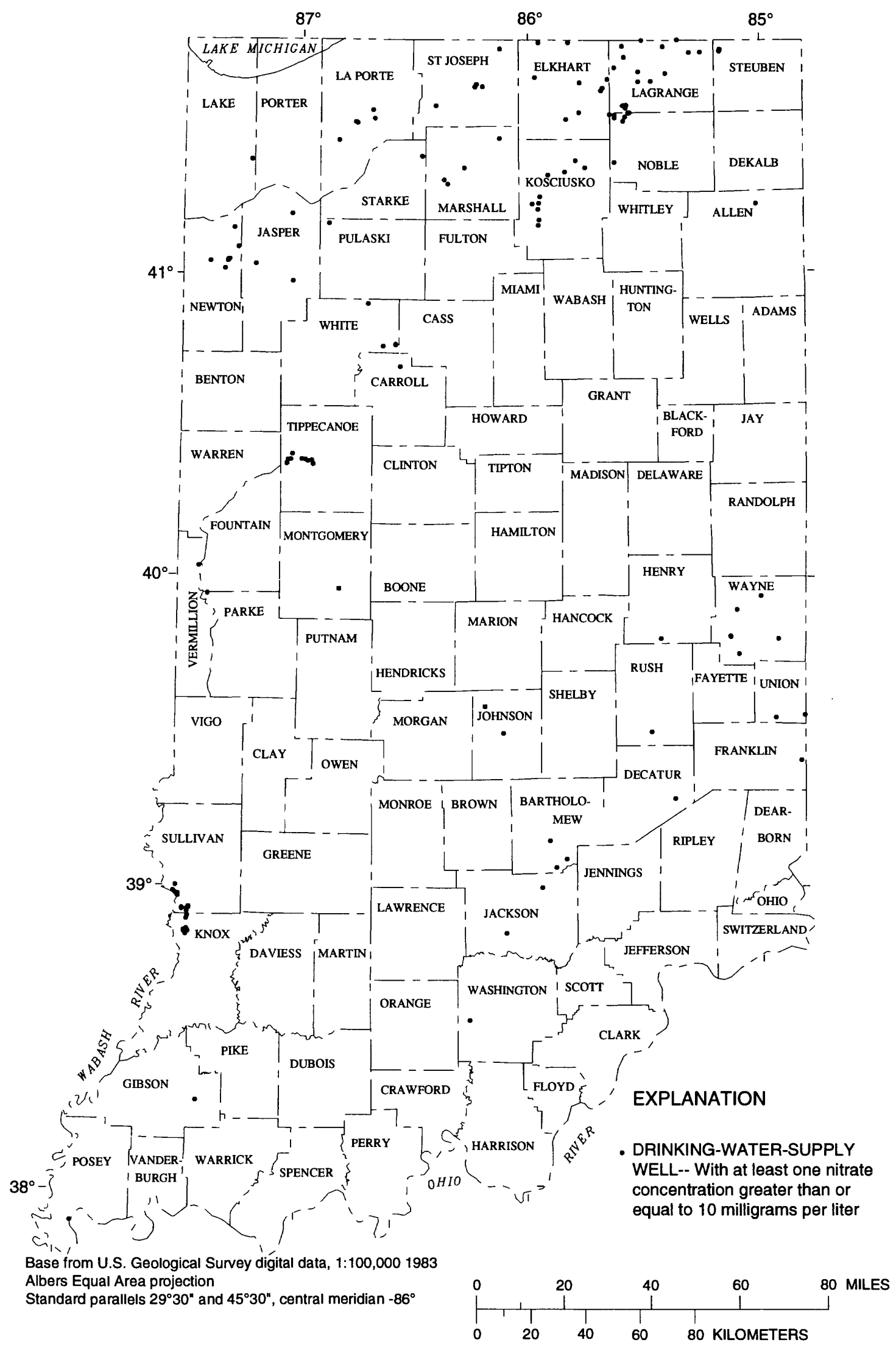

Figure 1. Locations of drinking-water-supply wells in Indiana with nitrate concentrations greater than or equal to 10 milligrams per liter during 1973-91. 

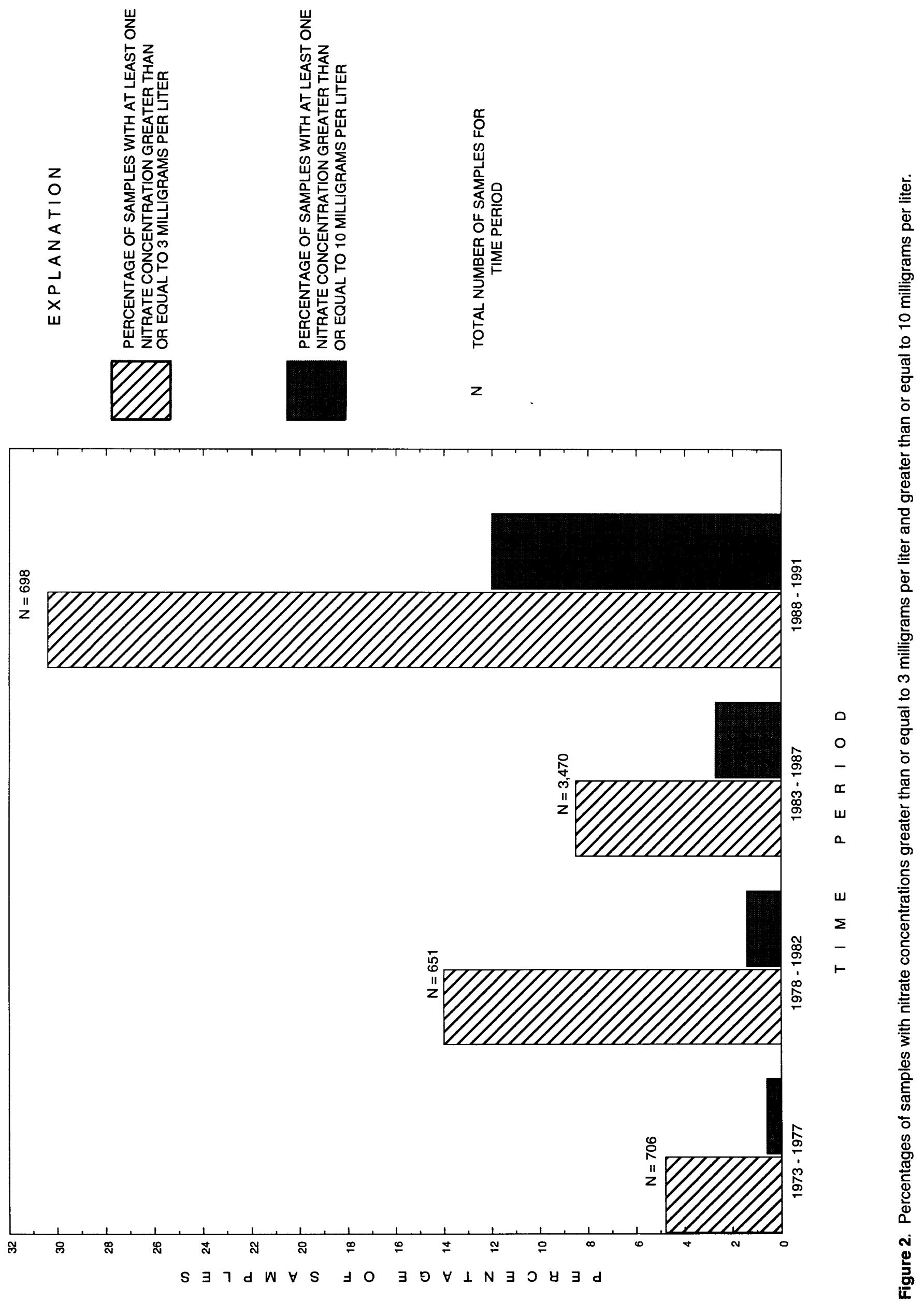


\section{REFERENCES CITED}

Bachman, L.J., 1984, Nitrate in the Columbian aquifer, central Delmarva Peninsula, Maryland: U.S. Geological Survey Water-Resources Investigation Report 84-4322, $51 \mathrm{p}$.

Clendenon, C.J. and Beaty, J.E., eds., 1987, Water resource availability in the St. Joseph River Basin, Indiana: State of Indiana Department of Natural Resources, p. 1.

Environmental Systems Research Institute, Inc., 1989, ARC/INFO user's guide, vol. 2, command references ( $2 \mathrm{~d}$ ed.): Redlands, Calif., 280 p.

Fishman, M.J. and Friedman, L.C., eds., 1989, Methods for determination of inorganic substances in water and fluvial sediments (3d ed.): U.S. Geological Survey Techniques of Water-Resources Investigations, book 5, chap. A1, $545 \mathrm{p}$.

Hamilton, P.A., Shedlock, R.J., and Phillips, P.J., 1989, Ground-water-quality assessment of the Delmarva Peninsula, Delaware, Maryland, and Virginia - analysis of available water-quality data through 1987: U.S. Geological Survey Open-File Report 89-34; 71 p.

Hardy, M.A., Leahy, P.P., and Alley, W.M., 1989, Well installation and documentation, and ground-water sampling protocols for the pilot National Water-Quality Assessment Program: U.S. Geological Survey Open-File Report 89-396, 36 p.

Hem, J.D., 1989, Study and interpretation of the chemical characteristics of natural water: U.S. Geological Survey Water-Supply Paper 2254, 263 p.

Hunger, J.M.; McSwane, D.Z.; Zollinger, T.W.; Jones, W.W.; 1986, A survey of non-community water supplies in the State of Indiana: Indianapolis, Indiana University School of Public and Environmental Affairs, 586 p.

Indiana Department of Environmental Management, 1990, Indiana 305(b) report 1988-89: Indianapolis, Indiana Department of Environmental Management, 315 p.

Kolpin, D.W. and Burkhart, M.R., 1991, Work plan for regional reconnaissance for selected herbicides and nitrate in ground water of the midcontinent United States, 1991: U.S. Geological Survey Open-File Report 91-59, 18 p.

Maddy, D.V., Lopp, L.E., Jackson, D.L., Coupe, R.H., and Schertz, T.L., 1989, National water information system user's manual, vol. 2, chap. 2, version 90.1 -water-quality system: U.S. Geological Survey Open-File Report 89-617, 218 p.
Madison, R.J. and Brunett, J.O., 1985, Overview of the occurrence of nitrate in ground water of the United States in National water summary 1984, Hydrologic events, selected water-quality trends, and ground-water resources: U.S. Geological Survey Water-Supply Paper 2275, p. 93-105.

Mathey, S.B., ed., 1989, National water information system user's manual, vol. 2 , chap. 4 , version 90.1-ground-water site inventory system: U.S. Geological Survey Open-File Report 89-587, 242 p.

Risch, M.R., 1994, A summary of pesticides in ground-water data collected by government agencies in Indiana, December 1985 to April 1991: U.S. Geological Survey OpenFile Report 93-133, 30 p.

Skougstad, M.W., Fishman, M.J., Friedman, L.C., Erdmann, D.E., and Duncan, S.S., eds., 1979, Methods for determination of inorganic substances in water and fluvial sediments: U.S. Geological Survey Techniques of Water-Resources Investigations, book 5, chap. A1, $626 \mathrm{p}$.

State Nonpoint Source Task Force, June 1989, Indiana nonpoint source water pollution management program: Indianapolis, Indiana Department of Environmental Management, 137 p.

U.S. Department of Agriculture, Indiana Agricultural Statistics Service, May 1991, Indiana agriculture report special issue-agriculture fertilizer and chemical usage, v.11, SP-5: West Lafayette, Ind., U.S. Department of Agriculture, $8 \mathrm{p}$.

U.S. Environmental Protection Agency, Office of Water, April 1992, Drinking water regulations and health advisories: Washington, D.C., 13 p.

U.S. Environmental Protection Agency, Office of Water, Office of Pesticides and Toxic Substances, Fall 1990, National pesticide summary-Summary results of EPA's national survey of pesticides in drinking water wells: Washington, D.C., 16 p.

Wood, W.W., 1981, Guidelines for collection and field analysis of ground-water samples for selected unstable constituents ( $2 \mathrm{~d}$ ed.): U.S. Geological Survey Techniques of Water-Resources Investigations, book 1, chap. D2, 24 p. 